Article

\title{
Systematic Investigation of Plant-Parasitic Nematodes Associated with Main Subtropical Crops in Guangxi Province, China
}

\author{
Yi-Xue Mo, Ai-Su Mo, Zhuo-Qiu Qiu, Bing-Xue Li and Hai-Yan Wu *D \\ Guangxi Key Laboratory of Agric-Environment and Agric-Products Safety, Agricultural College of \\ Guangxi University, Nanning 530004, China; 2017304017@st.gxu.edu.cn (Y.-X.M.); winter500@126.com (A.-S.M.); \\ athos0519@163.com (Z.-Q.Q.); 18437958381@163.com (B.-X.L.) \\ * Correspondence: wuhy@gxu.edu.cn
}

check for updates

Citation: Mo, Y.-X.; Mo, A.-S.; Qiu, Z.-Q.; Li, B.-X.; Wu, H.-Y. Systematic Investigation of Plant-Parasitic Nematodes Associated with Main Subtropical Crops in Guangxi Province, China. Life 2021, 11, 1177. https://doi.org/10.3390/ life11111177

Academic Editors: Yanfeng Hu, Fengjuan Pan, Jingsheng Chen and Francois Lefort

Received: 26 August 2021

Accepted: 1 November 2021

Published: 3 November 2021

Publisher's Note: MDPI stays neutral with regard to jurisdictional claims in published maps and institutional affiliations.

Copyright: (c) 2021 by the authors. Licensee MDPI, Basel, Switzerland. This article is an open access article distributed under the terms and conditions of the Creative Commons Attribution (CC BY) license (https:// creativecommons.org/licenses/by/ $4.0 /)$.

\begin{abstract}
Plant parasitic nematodes (PPNs) are a pathogenic group that causes momentous crop yield loss by retarding plant growth and development through plant parasitization. In this study, the distribution of PPNs based on the main crops in Guangxi Province of China was investigated. A total of 425 samples of soil or roots from sugarcane, rice, maize, and soybean were collected in 68 counties, and a total of 48 order/family/genera of PPNs were identified, of which some genera were found in more than one crop. A total of 31 order/family/genera of PPNs were found in rice, among which Hirschmanniella was the most abundant, accounting for $79.23 \%$, followed by Tylenchorhynchus (34.43\%). Forty order/family/genera were observed in maize, of which the dominant genera were Pratylenchus and Tylenchorhynchus at $45.14 \%$ and $32.64 \%$, respectively. In addition, 30 order/family/genera of PPNs were detected from sugarcane, and the percentages of Tylenchorhynchus and Helicotylenchus were $70.42 \%$ and $39.44 \%$, respectively. The main crop of Eastern ecological regions was rice, with a high frequency of Hirschmanniella. The greatest frequency of Pratylenchus was found in the Western eco-region, which had a large area of maize. In the Northern eco-region, rice and maize were popular, with abundant Hirschmanniella and Helicotylenchus. In the Central eco-region, Pratylenchus was detected on the main crop of sugarcane. Hirschmanniella $(72.94 \%)$ was dominant in clay, and Tylenchorhynchus (54.17\%) showed the highest frequency in loam. The distribution of PPNs varied with different altitudes. The diversity of this phenomenon was closely related to host plants. These results could improve understanding of the distribution of PPNs and provide important information for controlling PPNs.
\end{abstract}

Keywords: plant parasitic nematodes; rice; maize; sugarcane; soybean; geographical distribution

\section{Introduction}

Plant parasitic nematodes (PPNs) are a serious menace to a variety of crop plants worldwide. More than 4000 PPNs have been reported, resulting in over USD 173 billion of economic loss annually [1,2]. The plants infected by nematodes experience dwarfism, discoloration, and blocked absorption of nutrients, thereby seriously affecting the yield and quality of agricultural products [3,4]. Multiple PPNs have been implicated in disease complexes with plant pathogenic fungi and bacteria; for instance, soybean cyst nematode can aggravate sudden death syndrome (Fusarium virguliforme) in soybean [5,6].

The species and distribution of PPNs are closely related to different crops. Rice could be attacked by more than 200 plant pathogenic nematodes, and rice parasitic nematode disease has become increasingly serious with the promotion of water-saving cultivation mode [7], causing an annual loss of approximately USD 16 billion worldwide [8]. The main parasitic nematodes of rice include Meloidogyne spp., Aphelenchoides spp., Hirschmanniella spp., Ditylenchus spp., and Heterodera spp. [9]. M. graminicola can cause substantial yield losses, representing up to $87 \%$ of production [10]. In Guangxi, Heterodera elachista and 
Meloidogyne graminicola have been reported on rice [11,12]. At least 120 PPNs can parasitize maize worldwide, including more than 60 species in North America, and Pratylenchus spp. and Helicotylenchus spp. can cause immense harm to maize. Maize yield losses of $50 \%$ have been reported in Brazil, where lesion nematodes are present [13]. Several studies have uncovered PPNs diversity in sugarcane fields in countries such as Mauritius, India, Kenya, South Africa, Brazil, and Japan, revealing the most common PPNs genera associated with sugarcane as Meloidogyne, Pratylenchus, Tylenchorhynchus, Rotylenchulus, and Helicotylenchus [14]. In China, Tylenchorhychus spp., Helicotylenchus spp., Meloidogyne spp., and Pratylenchus spp. seriously damage sugarcane [15]. South Africa has reported $10-30 \%$ yield losses caused by PPNs, and greater than $40 \%$ of occasional yield reduction caused by PPNs was reported in Africa $[16,17]$. Soybean is also damaged by nematodes, such as Heterodera glycines, Meloidogyne incognita, and Rotylenchulus reniformis. Reports have pointed out that $H$. glycines can cause billions of dollars of economic losses worldwide and $30-50 \%$ of production reduction in Northeast China and Huanghuai soybean production areas [18-20].

The distribution of nematodes is also related to environmental factors, such as soil type, rainfall, and altitude. Studies have indicated that soil type could affect the abundance, diversity, distribution, and pathogenicity of nematodes [9,21]. A previous study has pointed out that nematodes have fewer species, but a higher density in clay and loam than in sand. The concentrations of Helicotylenchus spp. and Basiria spp. are relatively lower in sand than in clay and loam [22]. As for studies of altitude, nematode diversity was affected neither by altitude nor by layer. However, the community structure changed with altitude [23], whereas studies have pointed out that nematodes are mainly linear with altitude (low nematode abundance at high altitude) [24].

Guangxi Province is located in the west of southern China, covering an area of $236,700 \mathrm{~km}^{2}$. Rice, maize, sugarcane, and soybean are the main food and cash crops. The geographical distribution and groups of PPNs provide the basis for the control of nematode diseases. However, a systematic investigation has not been carried out, and the parasitic nematode on these crops remains unexplored. This study aimed to (1) identify to the genus level PPNs from the rhizosphere soil of main crops, (2) reveal the distribution of PPNs in different ecological areas and crops in Guangxi, and (3) understand the distribution of PPNs in different soil types and altitudes.

\section{Materials and Methods}

\subsection{Collection of Soil Samples}

Soil was collected in 2016-2017 from the rhizosphere of rice, maize, sugarcane, and soybean in 68 counties of 14 cities in Guangxi Province. One centimeter of topsoil was removed before soil sample collection at a $15 \mathrm{~cm}$ depth; $5-10$ cores around plants were collected with a soil auger in a Z-pattern in each plot [25]. The soil sample with some roots was placed in separate Ziploc bags and labeled with site, longitude, latitude, and altitude. They were then transported to the lab and stored at $4{ }^{\circ} \mathrm{C}$ for further analysis within 3 days.

\subsection{Extraction of Nematodes}

Roots from soil samples were collected by hand, the soil was gently mixed well, and the nematodes were extracted from a $100 \mathrm{~mL}$ soil sample using Cobb's sieving and decanting techniques through 40-, 100-, and 325-mesh sieves. The sediments on the 100-mesh sieve were carefully transferred on a $5-\mathrm{cm}$ diameter petri dish, and the cyst was examined under a stereoscopic microscope (Olympus SZX2-ILLT, Olympus Corporation, Tokyo, Japan). Nematodes were isolated from the collected sediments (on the 325-mesh sieve) using modified Baermann's funnel [26]. Roots were cleaned completely and cut into segments $0.5-\mathrm{cm}$ long to extract any nematodes using same method above. The nematodes were collected after 10-12 h; all extracted nematodes in each sample were identified using an optical microscope according to order, family, and genus (if possible) based on morphology [27]. The percent of genus nematode in all samples was calculated 
and expressed as a detection percentage $(\%)=$ (number of samples with a genus/total number of samples) $\times 100$.

\subsection{Soil Texture}

Soil texture was classified in accordance with the international classification standard of soil texture and divided into clay, loam, and sand.

\subsection{Ecological Regions in Guangxi Province}

Guangxi is located in the Southern frontier region of China at $21^{\circ} 38^{\prime}-26^{\circ} 23^{\prime} \mathrm{N}$ and $104^{\circ} 29^{\prime}-112^{\circ} 04^{\prime} \mathrm{E}$, which has a long sunshine time, high annual average temperature, and annual rainfall that vary greatly in regions. In accordance with the principle of climate similarity and the law of regional differentiation, taking the direction of agricultural development as the guidance, we comprehensively considered various factors for regional division [28,29]. Five ecological areas were divided into the Eastern Guangxi eco-region, Western Guangxi eco-region, Southern Guangxi eco-region, Northern Guangxi eco-region, and Central Guangxi eco-region.

\subsection{Figures}

All figures were created using SigmaPlot 12.5 and Photoshop 6.0.

\section{Results}

\subsection{Identification of PPNs at the Genus Level}

A total of 425 soil samples $(183,144,71$, and 27 samples from rice, maize, sugarcane, and soybean, respectively) were collected in fields located in the five ecological regions of Guangxi, and 48 order/family/genera of PPNs were identified (Table 1). The highfrequency genera included Tylenchorhynchus, Pratylenchus, Helicotylenchus, Meloidogyne, and Hirschmanniella in samples from rice, maize, sugarcane, or soybean.

In rice fields, 31 order / family / genera were observed, among which Hirschmanniella was the most abundant at $79.23 \%$, followed by Tylenchorhynchus at $34.43 \%$, and Filenchus and Meloidogyne at 26.78\%. The other genera, such as Pratylenchus and Helicotylenchus, occurred sporadically at less than $10 \%$.

Forty order/family/genera were detected in the soil samples from maize fields. Pratylenchus was associated with $45.14 \%$ of samples, followed by Tylenchorhynchus with $32.64 \%$, Helicotylenchus with $26.39 \%$, and Filenchus with $22.22 \%$. Heterodera zeae was only found in the maize field of Xiaopingyang Town, Laibin, and was first reported in China [30].

Thirty order/family/genera of PPNs were isolated from the rhizosphere soil of sugarcane. Tylenchorhynchus exhibited the highest frequency at $70.42 \%$, followed by Helicotylenchus at 39.44\%. Pratylenchus showed 35.21\% frequency, whereas Meloidogyne was not found in sugarcane.

Twenty-four order/family/genera from rhizosphere soil samples of soybean were found. Helicotylenchus was the most dominant, accounting for $33.33 \%$. The frequency of Tylenchorhynchus was 29.63\%, whereas Pratylenchus and Filenchus presented 25.93\% frequency, and the proportions of Aglenchus and Meloidogyne were both $11.11 \%$.

Tylenchorhynchus was found on the studied crops, which was arranged in the order from high to low frequency: sugarcane $(70.42 \%)>$ rice $(34.43 \%)>$ maize $(32.64 \%)>$ soybean $(29.63 \%)$. The frequency order of Hirschmanniella was as follows: rice $(79.23 \%)>$ maize $(9.03 \%)>$ sugarcane $(7.04 \%)>$ soybean $(3.70 \%)$. The order of Helicotylenchus on crops was as follows: sugarcane $(39.44 \%)>$ soybean $(33.33 \%)>$ maize $(26.39 \%)>$ rice $(4.38 \%)$. Pratylenchus displayed a high population, and the ratios were arranged in the following order: maize $(45.14 \%)>$ sugarcane $(35.12 \%)>$ soybean $(25.93 \%)>$ rice $(3.28 \%)$. Meloidogyne was not detected in sugarcane, and its ratio in rice, soybean, and maize was $26.78 \%, 11.11 \%$, and $3.47 \%$, respectively. 
Table 1. Genera and frequency ratio of plant parasitic nematodes detected in soil samples.

\begin{tabular}{|c|c|c|c|c|c|c|c|c|}
\hline \multirow{2}{*}{ Order/Family/Genus } & \multicolumn{2}{|c|}{ Rice } & \multicolumn{2}{|c|}{ Maize } & \multicolumn{2}{|c|}{ Sugarcane } & \multicolumn{2}{|c|}{ Soybean } \\
\hline & Samples & Ratio (\%) & Samples & Ratio (\%) & Samples & Ratio (\%) & Samples & Ratio (\%) \\
\hline Aglenchus & 8 & 4.37 & 9 & 6.25 & 5 & 7.04 & 3 & 11.11 \\
\hline Antarctylus & - & - & 2 & 1.39 & 1 & 1.41 & 1 & 3.70 \\
\hline Aphelenchoides & 7 & 3.83 & 3 & 2.08 & 7 & 9.86 & 2 & 7.41 \\
\hline Aphelenchus & 5 & 2.73 & 13 & 9.03 & 6 & 8.45 & 1 & 3.70 \\
\hline Basiria & 7 & 3.83 & 1 & 0.69 & - & - & 1 & 3.70 \\
\hline Boleodorus & 6 & 3.28 & 10 & 6.94 & 1 & 1.41 & - & - \\
\hline Bursaphelenchus & - & - & 1 & 0.69 & - & - & - & - \\
\hline Carphodrus & - & - & 1 & 0.69 & - & - & - & - \\
\hline Cephalenchus & - & - & 2 & 1.39 & - & - & 1 & 3.70 \\
\hline Coslenchus & 2 & 1.09 & 3 & 2.08 & 1 & 1.41 & - & - \\
\hline Criconemella & 3 & 1.64 & 1 & 0.69 & - & - & - & - \\
\hline Ditylenchus & 5 & 2.73 & 2 & 1.39 & 4 & 5.63 & 2 & 7.41 \\
\hline Dorylaimidae & 7 & 3.83 & 2 & 1.39 & 4 & 5.63 & - & - \\
\hline Dorylaimoidea & 128 & 69.95 & 71 & 49.31 & 30 & 42.25 & 17 & 62.96 \\
\hline Ecphyadophoroides & 1 & 0.55 & - & - & - & - & - & - \\
\hline Filenchus & 49 & 26.78 & 32 & 22.22 & 12 & 16.90 & 7 & 25.93 \\
\hline Gracilacus & - & - & - & - & 1 & 1.41 & - & - \\
\hline Helicotylenchus & 17 & 9.28 & 38 & 26.39 & 28 & 39.44 & 9 & 33.33 \\
\hline Hemicriconemoides & 6 & 3.28 & - & - & - & - & 1 & 3.70 \\
\hline Hemicycliophora & - & - & - & - & 1 & 1.41 & - & - \\
\hline Heterodera & - & - & 1 & 0.69 & - & - & - & - \\
\hline Hirschmanniella & 145 & 79.23 & 13 & 9.03 & 5 & 7.04 & 1 & 3.70 \\
\hline Hoplolaimidae & - & - & 2 & 1.39 & 1 & 1.41 & 1 & 3.70 \\
\hline Hoplolaimus & 2 & 1.09 & 1 & 0.69 & 7 & 9.86 & 2 & 7.41 \\
\hline Longidoridae & 6 & 3.28 & 8 & 5.56 & 2 & 2.82 & 1 & 3.70 \\
\hline Longidorus & 1 & 0.55 & 2 & 1.39 & 3 & 4.23 & - & - \\
\hline Malenchus & 4 & 2.19 & 5 & 3.47 & 1 & 1.41 & - & - \\
\hline Meloidogyne & 49 & 26.78 & 5 & 3.47 & - & - & 3 & 11.11 \\
\hline Miculenchus & 4 & 2.19 & 5 & 3.47 & 1 & 1.41 & 1 & 3.70 \\
\hline Neopsilenchus & - & - & 2 & 1.39 & 2 & 2.82 & - & - \\
\hline Paraphelenchus & 4 & 2.19 & 5 & 3.47 & - & - & - & - \\
\hline Pararotylenchus & - & - & 5 & 3.47 & 9 & 12.68 & 2 & 7.41 \\
\hline Paratrichodorus & - & - & 1 & 0.69 & 2 & 2.82 & - & - \\
\hline Paratylenchus & - & - & - & - & - & - & 1 & 3.70 \\
\hline Pratylenchoides & - & - & - & - & 1 & 1.41 & - & - \\
\hline Pratylenchus & 6 & 3.28 & 65 & 45.14 & 25 & 35.21 & 7 & 25.93 \\
\hline Psilenchus & 1 & 0.55 & 4 & 2.78 & - & - & 1 & 3.70 \\
\hline Rhabdotylenchus & 1 & 0.55 & 1 & 0.69 & 1 & 1.41 & - & - \\
\hline Rotylenchulus & 1 & 0.55 & 2 & 1.39 & 1 & 1.41 & - & - \\
\hline Rotylenchus & 2 & 1.09 & 17 & 11.81 & 7 & 9.86 & 1 & 3.70 \\
\hline Scutellonema & - & - & 1 & 0.69 & - & - & - & - \\
\hline Trichodorus & - & - & 2 & 1.39 & 6 & 8.45 & - & - \\
\hline Triplonchida & - & - & 4 & 2.78 & - & - & - & - \\
\hline Tylenchidae & 1 & 0.55 & - & - & - & - & - & - \\
\hline Tylenchorhynchus & 63 & 34.43 & 47 & 32.64 & 50 & 70.42 & 8 & 29.63 \\
\hline Tylenchus & 1 & 0.55 & 3 & 2.08 & - & - & 1 & 3.70 \\
\hline Xiphidorus & 1 & 0.55 & - & - & - & - & - & - \\
\hline Zygotylenchus & - & - & 1 & 0.69 & - & - & - & - \\
\hline
\end{tabular}

\subsection{Occurrence of PPNs in Five Ecological Regions in Guangxi}

The main crop in the Eastern eco-region is rice. The ratio of PPNs in this region was in the order of Tylenchorhynchus $>$ Hirschmanniella $>$ Pratylenchus $>$ Meloidogyne $>$ Helicotylenchus. Maize is the main crop in Baise, which belongs to the Western eco-region. The proportion of PPNs in this region was Helicotylenchus $>$ Pratylenchus $>$ Hirschmanniella $>$ Meloidogyne > Tylenchorhynchus. The Southern eco-region includes Qinzhou, Fangchenggang, and Beihai. Rice and sugarcane are planted more in this region than any other crops. 
Guilin, Liuzhou, and Hechi belong to the Northern eco-region, and the principal crops are rice and maize. Tylenchorhynchus was dominant, followed by Hirschmanniella, Helicotylenchus, Pratylenchus, and Meloidogyne. In the Central eco-region, including Chongzuo, Nanning, and Laibin, the main crop was sugarcane, in which Tylenchorhynchus presented a high frequency. In contrast, Hirschmanniella, Pratylenchus, Helicotylenchus, and Meloidogyne displayed low population densities (Figure 1, Supplementary Table S1).

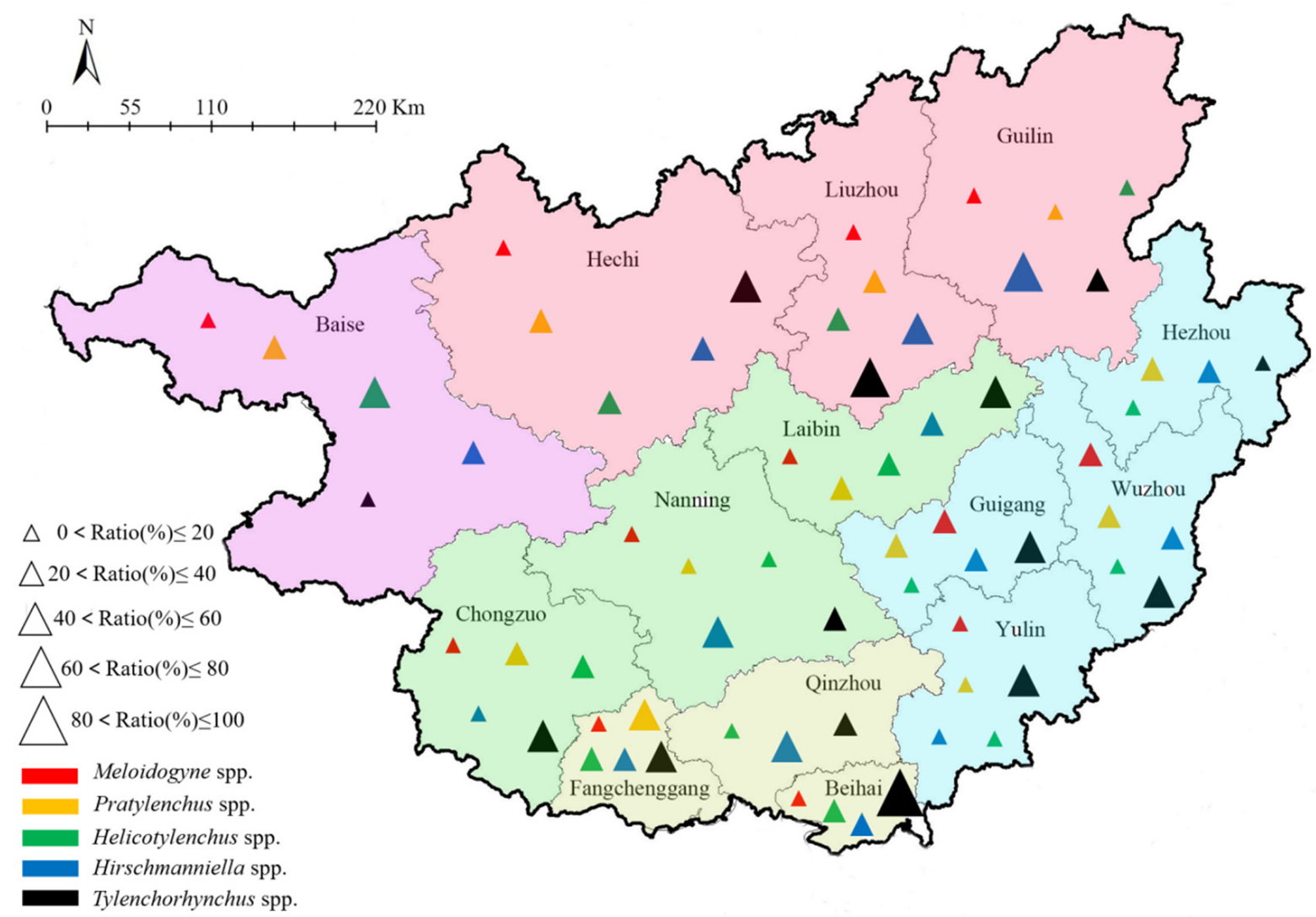

Figure 1. Distribution and proportion of major plant parasitic nematodes in different regions and cities.

\subsection{Main PPNs in Different Soil Textures}

The results indicated that the distribution of PPNs was distinguished in different soil textures. In loam texture, the frequency sequence of the sampled crops was as follows: maize $(51.39 \%)>$ sugarcane $(26.39 \%)>$ rice $(16.67 \%)>$ soybean $(5.55 \%)$. Tylenchorhynchus displayed a high frequency, detected in $54.17 \%$, and Pratylenchus accounted for $50 \%$ of the soil samples. Helicotylenchus and Hirschmanniella accounted for $31.94 \%$ and $26.39 \%$ of the analyzed samples, respectively, whereas Meloidogyne accounted for $2.78 \%$.

In clay, the main planted crop was rice $(90.59 \%)$, with a small amount of maize and sugarcane at $4.71 \%$ and $4.70 \%$, respectively. The percentage of nematodes was in the order of Hirschmanniella $(72.94 \%)>$ Tylenchorhynchus $(38.82 \%)>$ Meloidogyne $(21.18 \%)>$ Helicotylenchus $(10.59 \%)>$ Pratylenchus $(5.88 \%$, Table 2, Figure 2).

Table 2. Proportion (\%) of main crops with different soil textures in this survey.

\begin{tabular}{ccccc}
\hline Soil Texture & Rice & Maize & Sugarcane & Soybean \\
\hline Loam & 16.67 & 51.39 & 26.39 & 5.55 \\
Clay & 90.59 & 4.71 & 4.70 & 0 \\
\hline
\end{tabular}




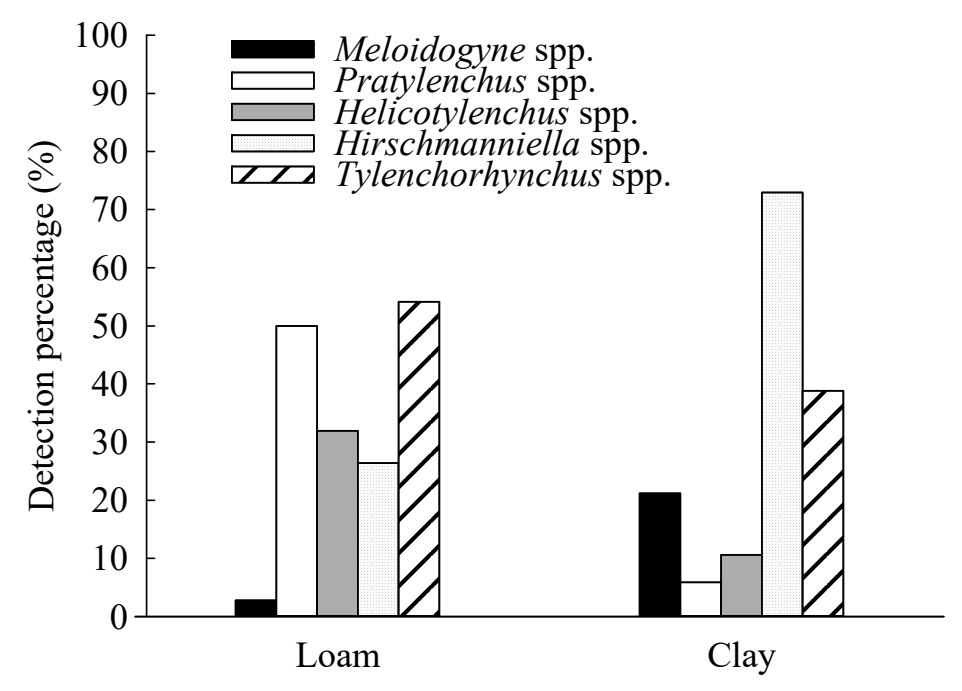

Figure 2. Detection percentage of plant parasitic nematodes in loam and clay soil.

\subsection{PPNs in Regions with Different Altitudes}

The distribution of PPNs varies at different altitudes. In contrast, some nematodes were distributed at all altitudes (Table 3), which were Tylenchorhynchus, Hirschmanniella, Meloidogyne, Pratylenchus, Helicotylenchus, Filenchus, Aglenchus, Pararotylenchus, Rotylenchus, Aphelenchus, Lelenchus, Helicotylenchus crenacauda, Bolendorus, Paraphelenchus, Coslenchus, Aphelenchoides, Ditylenchus, and Dorylaimoidea respectively. At $<50 \mathrm{~m}$ altitude, 25 order/family/genera were detected, with the frequencies of $42.55 \%$ and $45.68 \%$ for Hirschmanniella and Tylenchorhynchus, respectively. At 50-100 m altitude, 40 nematodes genera were found; the highest percentage was Tylenchorhynchus (42.86\%). There were 28 order/family/genera at 100-150 m altitude, of which the most detected was Hirschmanniella with the frequency of $42.15 \%$. Hirschmanniella and Tylenchorhynchus exhibited the same frequencies of $41.79 \%$ at $150-200 \mathrm{~m}$ altitude in 31 order/family/genera. When the altitude was $>200 \mathrm{~m}$ among 30 kinds of PPNs, the nematode with the highest frequency was Hirschmanniella with $46.67 \%$.

Table 3. PPNs and crops at different altitudes.

\begin{tabular}{cccc}
\hline Altitude (m) & Number of Soil Samples & Number of Family/Genus & Main Crop \\
\hline$<50$ & 47 & 25 & Rice \\
$50-100$ & 126 & 40 & Rice, Maize \\
$100-150$ & 121 & 28 & Rice \\
$150-200$ & 67 & 31 & Maize \\
$>200$ & 60 & 30 & Rice \\
\hline
\end{tabular}

\section{Discussion}

In the present study, the PPNs in five ecological regions of Guangxi were investigated. On the basis of the morphological characteristics, 48 genera of PPNs were observed, and the important PPNs, including cyst nematode on maize and root knot nematode on rice, were identified as Heterodera zeae and M. graminicola [12,30]. The distribution of nematodes varied in different hosts, ecological regions, soil textures, and altitudes.

The large-scale occurrence of nematodes is closely related to continuous cropping, and the disease caused by nematodes is serious in the soil where nematodes are abundant [31]. In Ecuador, Hirschmanniella was frequently found in irrigated rice, whereas Pratylenchus had the greatest frequency in rainfed lowland rice; Helicotylenchus, Criconemoides, and Tylenchorhynchus were also abundant in rice fields [32]. In the present study, Hirschmanniella, Meloidogyne, Tylenchorhynchus, and Filenchus were dominant in rice and the detection frequency of Hirschmanniella was $79.23 \%$, and this nematode was distributed in all rice areas 
in Guangxi; nine species of Hirschmanniella were identified and described in Guangdong Province. They are Hirschmanniella areolata, H. behningi, H. anchoryzae, $H$. caudacrea, $H$. diversa, H. Meloidogyne spp. Pratylenchus spp. Helicotylenchus spp. Hirschmanniella spp. Tylenchorhynchus spp. orycrena, H. oryzae, H. microtyla, and H. mucronata [33]. Thus, this is a great potential threat to rice-growing areas. It also occurred in a large area in Fujian and Jiangsu Provinces in China [34].

Maize had the most abundant parasitic nematodes in this survey. The dominant nematodes were Pratylenchus and Tylenchorhynchus, and the result was similar to the previous investigation on maize in Hebei, Shanxi, Henan, Shandong, and Jiangsu [35]. Pratylenchus is widely distributed, and a total of 100 species of Pratylenchus have been recorded worldwide [36]. The largest number of parasitic nematode genera in maize was identified in the present study, most of which had been previously reported. Heterodera zeae was first observed in China [30], which was considered a quarantined organism in the United States [37]. Previous studies on maize parasitic nematodes have primarily concentrated in Central and Northern China, and such nematodes have not been well explored in the Southern China. The present study provided a reference to parasitic nematodes in maize in Southern China. The results showed that the main parasitic nematodes were similar to North China, except Heterodera zeae was first reported on maize.

Over 310 species belonging to 48 genera have been reported from roots or rhizosphere of sugarcane, and Meloidogyne, Pratylenchus, and Xiphinema are the most economically damaging nematodes found in sugarcane [38]. Thirty genera of parasitic nematodes on sugarcane were observed in this study. Tylenchorhynchus, Helicotylenchus, and Pratylenchus were the dominant populations. P. zeae was frequently regarded as highly pathogenic to sugarcane [38,39].

Heterodera, Meloidogyne, or Pratylenchus cause severe damage in the main soybeanproducing regions worldwide [40]. However, in this study, PPNs from soybean soil samples were Tylenchorhynchus and Helicotylenchus, which were widely distributed in Guangxi. In contrast, in Germany Pratylenchus was widely spread in soybean fields followed by Rotylenchus and Paratylenchus [41], probably because of the different geographical conditions and crop factors. In the present study, the small number of samples from soybean possibly resulted in the few nematode genera detected. Most studies on soybean parasitic nematodes have focused on H. glycines [42], which was not observed in this investigation.

Tylenchorhynchus, Hirschmanniella, Helicotylenchus, Pratylenchus, and Meloidogyne were the main genus observed in the five ecological regions. Rice was cultivated profusely in Eastern and Southern eco-regions; thus, a large proportion of Hirschmanniella was detected in the present research. Nematodes were associated with rice, wheat, maize, and legumes in Bangladesh, Nepal, and Pakistan [43]. Maize was the main crop in the Western eco-region, where a high frequency of Pratylenchus was presented. Rice and maize were common crops in the Northern eco-region, where Hirschmanniella and Helicotylenchus were observed the most. Sugarcane was primarily cultivated in the Central eco-region, where a high frequency of Pratylenchus was detected. These results suggest that the distribution of nematodes in different ecological regions was closely related to the main crop in the corresponding region.

Although the growth and pathogenicity of PPNs are influenced by soil conditions, including soil texture, moisture, and aeration in field soils [44], the compatibility between plant nematodes and their hosts is highly important. Therefore, rice in Guangxi is grown in clay soil, and Hirschmanniella can be found most frequently in clay.

Tsiafouli et al. [45] recently concluded that, among the factors that affect the nematode community, altitude was the most predictable because altitudinal climatic conditions strongly constrain the availability and turnover of basal resources, leading to the difference of nematode occurrence. Simultaneously, host plants affected the occurrence of nematodes in our study. 
The present study pointed out that the PPNs were primarily distributed at 50-200 m, whereas fewer genera were distributed at $<50$ or $>200 \mathrm{~m}$ altitude. The distinction among the results may be due to the crops being cultivated at different altitudes.

On account of samples, Dorylaimoidea nematodes were not identified at the genus level. The importance of this nematode group lies not only in their polyphagy and wide distribution but also in their status as vectors of plant viruses, which cause significant damage to a wide range of agricultural crops [46]. The dagger nematode Xiphinema index caused severe damage to grapevines, an essential crop in most Mediterranean countries; apart from the direct damage to the root, resulting in the typical stubby root with terminal swellings, $X$. index serves as the vector for grapevine fanleaf virus $[47,48]$. In addition, Filenchus has a high frequency in the present study; however, its importance as a plant pathogen is unknown [27].

\section{Conclusions}

Forty-eight order/family/genera of PPNs were observed on main subtropical crops in Guangxi province in this study, among which five had the highest frequency, including Tylenchorhynchus, Pratylenchus, Helicotylenchus, Meloidogyne, and Hirschmanniella. It was the host plants rather than soil texture and altitude that was closely related to the occurrence of PPNs. The results highlighted the need to monitor the population of Hirschmanniella in rice, Pratylenchus in maize, Tylenchorhynchus in sugarcane, and Helicotylenchus in soybean to protect crops. Effective control measures should be taken to control the nematode population in the future on the basis of nematode distribution on crops in ecological regions.

Supplementary Materials: The following are available online at https:/ / www.mdpi.com/article/10 $.3390 /$ life11111177/s1, Table S1: Proportion of major plant parasitic nematodes in different ecological regions.

Author Contributions: Conceptualization, A.-S.M.; methodology, Z.-Q.Q.; validation, B.-X.L.; resources, H.-Y.W.; writing-original draft preparation, Y.-X.M. and B.-X.L.; writing-review and editing, Y.-X.M., B.-X.L. and H.-Y.W.; supervision, H.-Y.W.; project administration, H.-Y.W.; funding acquisition, H.-Y.W. All authors have read and agreed to the published version of the manuscript.

Funding: This research was sponsored by the Guangxi Natural Science Foundation (2020GXNSFDA297003) and the National Natural Science Foundation of China (32160627).

Institutional Review Board Statement: Not applicable.

Informed Consent Statement: Not applicable.

Data Availability Statement: Data for this study can be made available with reasonable request to the authors.

Conflicts of Interest: The authors declare no conflict of interest.

\section{References}

1. Jones, J.T.; Haegeman, A.; Danchin, E.G.J.; Gaur, H.S.; Helder, J.; Jones, M.G.K.; Kikuchi, T.; Manzanilla-López, R.; Palomares-Rius, J.E.; Wesemael, W.M.L.; et al. Top 10 plant-parasitic nematodes in molecular plant pathology. Mol. Plant Pathol. 2013, 14, 946-961. [CrossRef]

2. Elling, A.A. Major emerging problems with minor Meloidogyne species. Phytopathology 2013, 103, 1092-1102. [CrossRef]

3. Rehman, S.; Gupta, V.K.; Goyal, A.K. Identification and functional analysis of secreted effectors from phytoparasitic nematodes. BMC Microbiol. 2016, 16, 48. [CrossRef]

4. Zhao, J.; Peng, D.L.; Liu, S.M. Progresses in the researches on the effectors of plant parasitic nematodes. J. Plant Prot. 2020, 47, 245-254.

5. Back, M.A.; Haydock, P.P.J.; Jenkinson, P. Disease complexes involving plant parasitic nematodes and soilborne pathogens. Plant Pathol. 2002, 51, 683-697. [CrossRef]

6. Roth, M.G.; Noel, Z.A.; Wang, J.; Warner, F.; Byrne, A.M.; Chilvers, M.I. Predicting soybean yield and sudden death syndrome development using at-planting risk factors. Phytopathology 2019, 109, 1710-1719. [CrossRef]

7. De Waele, D.; Elsen, A. Challenges in tropical plant nematology. Annu. Rev. Phytopathol. 2007, 45, 457-485. [CrossRef] 
8. Lilley, C.J.; Kyndt, T.; Gheysen, G. Nematode Resistant GM Crops in Industrialised and Developing Countries. In Genomics and Molecular Genetics of Plant-Nematode Interactions, 1st ed.; John, J., Godelieve, G., Carmen, F., Eds.; Springer: Berlin, Germany, 2001; pp. 517-541.

9. Namu, J.; Karuri, H.; Alakonya, A.; Nyaga, J.; Njeri, E. Distribution of parasitic nematodes in Kenyan rice fields and their relation to edaphic factors, rainfall and temperature. Trop. Plant Pathol. 2017, 43, 128-137. [CrossRef]

10. Mantelin, S.; Bellafiore, S.; Kyndt, T. Meloidogyne graminicola: A major threat to rice agriculture. Mol. Plant Pathol. 2017, 18, 3-15. [CrossRef] [PubMed]

11. Xie, J.L.; Yang, F.; Huang, W.K.; Peng, D.L.; Peng, Y.L.; Ji, H.L. Advances in major rice parasitic nematodes in recent years. J. Plant Prot. 2017, 44, 940-949.

12. Luo, M.; Li, B.X.; Wu, H.Y. Incidence of the rice root-knot nematode, Meloidogyne graminicola, in Guangxi, China. Plant Pathol. J. 2020, 36, 297-302. [CrossRef] [PubMed]

13. Singh, P.R.; Kashando, B.E.; Couvreur, M.; Karssen, G.; Bert, W. Plant-parasitic nematodes associated with sugarcane in Kilimanjaro, Tanzania. J. Nematol. 2020, 52, e2020-59. [CrossRef] [PubMed]

14. Kawanobe, M.; Sugihara, S.; Miyamaru, N.; Yoshida, K.; Nonomura, E.; Oshiro, H.; Toyota, K. Distribution of root-lesion and stunt nematodes, and their relationship with soil properties and nematode fauna in sugarcane fields in Okinawa, Japan. Agronomy 2020, 10, 762. [CrossRef]

15. Wei, J.L.; Huang, C.H.; Shang, X.K.; Pan, X.H.; Huang, D.F.; Wang, B.H. Nematode species and their distribution in sugarcane fields in Guangxi. J. South. Agric. 2012, 43, 184-186.

16. Spaull, V.W.; Cadet, P. Impact of nematodes on sugarcane and the benefit of tolerant varieties. Proc. S. Afr. Sug. Technol. Ass. 2003, 77, 230-238.

17. Blair, B.L.; Stirling, G.R. The role of plant-parasitic nematodes in reducing yield of sugarcane in fine-textured soils in Queensland, Australia. Aust. J. Exp. Agr. 2007, 47, 620-634. [CrossRef]

18. Koenning, S.R.; Wrather, J.A. Suppression of soybean yield potential in the continental United States from plant diseases estimated from 2006 to 2009. Plant Health Progr. 2010, 10, 1094.

19. Allen, T.W.; Bradley, C.A.; Sisson, A.J.; Byamukama, E.; Chilvers, M.I.; Coker, C.M.; Collins, A.A.; Damicone, J.P.; Dorrance, A.E.; Dufault, N.S.; et al. Soybean yield loss estimates due to diseases in the United States and Ontario, Canada, from 2010 to 2014. Plant Health Progr. 2017, 18, 19-27. [CrossRef]

20. Long, H.B.; Chen, W.; Pei, Y.L.; Feng, T.Z.; Sun, Y.F. Occurrence and distribution of Heterodera glycines in Guizhou Province. Plant Prot. 2017, 43, 173-176+186.

21. Coyne, D.L.; Smith, M.; Plowright, R. Plant parasitic nematode populations on upland and hydromorphic rice in Côte d'ivoire: Relationships with moisture availability and crop development on a valley slope. Agric. Ecosyst. Environ. 2001, 84, 31-43. [CrossRef]

22. McSorley, R.; Wang, K.H.; Kokalis-Burelle, N.; Church, G. Effects of soil type and steam on nematode biological control potential of the rhizosphere community. Nematropica 2006, 36, 197-214.

23. Walter, T.; Nicola, R.; Valentyna, K.; Nabil, M.; Stefan, S. Diversity and distribution of soil micro-invertebrates across an altitudinal gradient in a tropical montane rainforest of Ecuador, with focus on free-living nematodes. Pedobiologia 2017, 62, 28-35.

24. Liu, J.; Yang, Q.; Siemann, E.; Huang, W.; Ding, J.Q. Latitudinal and altitudinal patterns of soil nematode communities under tallow tree (Triadica sebifera) in China. Plant Ecol. 2019, 220, 965-976. [CrossRef]

25. Luquini, L.; Barbosa, D.; Haddad, F.; Ferreira, C.F.; Amorim, E.P. Nematode survey and biochemical characterization of Meloidogyne spp. in a main banana production area in Brazil. Crop Prot. 2019, 117, 94-99. [CrossRef]

26. Wu, H.Y.; Silva, J.O.; Becker, J.S.; Becker, J.O. Fluazaindolizine mitigates plant-parasitic nematode activity at sublethal dosages. J. Pest Sci. 2021, 94, 573-583. [CrossRef]

27. Xie, H. Taxonomy of Plant Nematodes; Anhui Science and Technology Press: Hefei, China, 2000.

28. Peng, G.; Ma, L. Climate Impact Assessment of Meteorological Business Series Training Materials for Grass-Roots Stations; China Meteorological Press: Beijing, China, 2016.

29. Lin, X.S. Research progress in the agroclimatic resources. J. Hainan Norm. Univ. (Nat. Sci.) 2003, 16, 87-91.

30. Wu, H.Y.; Qiu, Z.Q.; Mo, A.S.; Li, J.Q.; Peng, D.L. First report of Heterodera zeae on maize in China. Plant Dis. 2017, 101, 1330. [CrossRef]

31. Karuri, H.W.; Olago, D.; Neilson, R.; Mararo, E.; Villinger, J. A survey of root knot nematodes and resistance to Meloidogyne incognita in sweet potato varieties from Kenyan fields. Crop Prot. 2017, 92, 114-121. [CrossRef]

32. Gilces, C.T.; Santillán, D.N.; Velasco, L.V. Plant-parasitic nematodes associated with rice in Ecuador. Nematropica 2016, 46, 45-53.

33. Liu, S.T. Identification of Hirschmanniella spp. (Nematoda: Pratylenchidae) Extracted from Rice Root in Guangdong Province and a Loop-Mediated Isothermal Amplification Assay for Detection of Hirschmanniella oryzae. Master's Thesis, South China Agricultural University, Guangzhou, China, 2017.

34. Chen, L.H. Study on the Identification of Meloidogyne spp. in Anhui. J. Agric. Catastrophol. 2017, 7, 8-11.

35. Gao, X.B.; Cheng, H.R.; Fang, Z.D. Pathogen Identification and Pathogenicity of the Corn Disease Caused by Lesion Nematodes in North China. J. Nanjing Agric. Univ. 1992, 15, 50-56. 
36. Singh, P.R.; Nyiragatare, A.; Janssen, T.; Couvreur, M.; Decraemer, W.; Bert, W. Morphological and molecular characterisation of Pratylenchus rwandae n. sp. (Tylenchida: Pratylenchidae) associated with maize in Rwanda. Nematology 2018, $20,781-794$. [CrossRef]

37. Ringer, C.E.; Sardanelli, S.; Krusberg, L.R. Investigations of the host range of the corn cyst nematode, Heterodera zeae from Maryland. J. Nematol. 1987, 1, 97-106.

38. Cadet, P.; Spaull, V.W. Nematode parasites of sugarcane. In Plant Parasitic Nematodes in Subtropical and Tropical Agriculture, 2nd ed.; Luc, M., Sikora, R.A., Bridge, J., Eds.; CABI Publishing: Wallingford, UK, 2005; pp. 645-674.

39. Wang, H.; Zhuo, K.; Ye, W.; Liao, J. Morphological and molecular charaterisation of Pratylenchus parazeaen sp. (Nematoda: Pratylenchidae) parasitizing sugarcane in China. Eur. J. Plant Pathol. 2015, 143, 173-191. [CrossRef]

40. Sikora, R.A.; Greco, N.; Silva, J.F.V. Nematode parasites of food legumes. In Plant Parasitic Nematodes in Subtropical and Tropical Agriculture, 2nd ed.; Luc, M., Sikora, R.A., Bridge, J., Eds.; CABI Publishing: Wallingford, UK, 2005; pp. 259-318.

41. Elhady, A.; Heuer, H.; Hallmann, J. Plant parasitic nematodes on soybean in expanding production areas of temperate regions. J. Plant Dis. Protec. 2018, 125, 567-576. [CrossRef]

42. Shaibu, A.S.; Li, B.; Zhang, S.; Sun, J. Soybean cyst nematode-resistance: Gene identification and breeding strategies. Crop J. 2020, 8, 892-904. [CrossRef]

43. Munir, A.; Pokharel, R.R.; Bridge, J. Nematode management in subsistence farming in Bangladesh, Nepal and Pakistan. Nematology 2000, 4, 136-137.

44. Kim, E.; Seo, Y.; Kim, Y.S.; Park, Y.; Kim, Y.H. Effects of soil textures on infectivity of root-knot nematodes on carrot. Plant Pathol. J. 2017, 33, 66-74. [CrossRef]

45. Tsiafouli, M.A.; Bhusal, D.R.; Sgardelis, S.P. Nematode community indices for microhabitat type and large-scale landscape properties. Ecol. Indic. 2017, 73, 472-479. [CrossRef]

46. Cai, R.; Archidona Yuste, A.; Cantalapiedra Navarrete, C.; Palomares Rius, J.E.; Castillo, P. New evidence of cryptic speciation in the family Longidoridae (Nematoda: Dorylaimida). J. Zool. Syst. Evol. Res. 2020, 58, 869-899. [CrossRef]

47. Aballay, E.; Sepúlveda, R.; Insunza, V. Evaluation of five nematode-antagonistic plants used as green manure to control Xiphinema index Thorne et Allen on Vitis vinifera L. Nematropica 2004, 34, 45-51.

48. Oka, Y. Nematicidal activity of fluensulfone compared to that of organophosphate and carbamate nematicides against Xiphinema index and Longidorus vineacola. Eur. J. Plant Pathol. 2019, 154, 565-574. [CrossRef] 